UDC338.24:005.35

DOI: $10.21847 / 1728-9343.2017 .6(152) .122329$

\title{
DIELINI MARYNA,
}

PhD in economics, associate professor,

Department of Management, information-analytical activity and euro integration,

National Pedagogic Dragomanov University

\section{DEVELOPMENT OF SOCIAL RESPONSIBILITY OF BUSINESS IN CHINA: EXPERIENCE FOR UKRAINE}

The article presents a theoretical review of state regulation of corporate social responsibility in China. The basic legislative acts regulating this sphere are defined. Obligatory social reporting for state-owned enterprises is indicated. It was noted that an important area of regulation of social responsibility of business by the state is the environment, due to the high level of pollution and industrial character of the country's economy. The directions for the development of Ukrainian socio-economic responsibility of entrepreneurship based on China's experience are determined.

Key words: socio-economic responsibility of entrepreneurship; corporate social responsibility; social reporting; charity; state-owned enterprises.

The problem statement. The experience of foreign countries that have achieved certain results in the area of social responsibility of business (hereinafter, CSR), as well as those who are just beginning to attract attention to this topic, is useful in developing socio-economic responsibility of entrepreneurship (hereinafter, SERE) in Ukraine. In previous studies, the author has already studied the experience of India as the first country that has introduced compulsory deductions for charity, depending on the size of profits. Another of the countries that Ukraine can benefit from its experience, is China, a world leader in the development of its economy. The Chinese Government has also drawn attention to the development of CSR due to the negative environmental situation in the country - this is one of the main issues of Chinese CSR, as well as the development of charity, volunteering and the protection of workers' rights.

Analysis of recent research and publications. The analysis of the development of CSR in China has paid attention to scientists: Buhmann K. [2], Dia N. [9], Li B., Morse S., Parsa S., Tang B. [8], Tang G., Zhang D., Kambhamptati $U$. [3]. Their work laid the foundation for this research and further developed in identifying areas for applying China's experience to the SERE of Ukraine.

The purpose of the study is to study China's experience in developing of CSR in its country and on the basis of this to determine directions of development of the SERE in Ukraine.

Research and results. The fact of increasing priority of Chinese CSR during last year's is based on the growing interest in sustainable development of Chinese society. It is also very important sign due to China's leading position in worldwide production chain.

The great role of increasing attention to CSR in China belongs to the government, that actively works on legislative base and provides guidelines to develop the safety of products and people, and encourage sustainable development of the economy. Nowadays entrepreneurships have already come to conclusion that CSR is not only benefit for people, environmental and their profit. As proof of this foreign companies that operate on Chinese market under- stand that they benefit from the CSR by strengthening their market position.

In spite of the fact that CSR is becoming a 'business case' in China, it is still problematic point in compliance with legislation at the whole. It is also essential for an effective CSR business strategy to know all cultural and social features of Chinese society.

Attention to environmental and social responsibility is now paid not only by foreign, but also domestic Chinese companies that is shown in recent surveys [2].

CSR topics in China now are interconnected with "harmonious society" - the concept that is built on the base of Confucius study and aimed to develop stable and harmonic Chinese society.

As now is their 13th five-yearplan (2016-2020), this concept plays a great role in its realization. In accordance with this plan there are issued different CSR norms and guidelines by Industry associations and local authorities. Besides, in 2008 it was introduced at the legislative level the obligation of state-owned companies to do annual CSR reports and publish them.

The Chinese government and CSR China is a political economy with a multitude of ministries and central government bodies which may be relevant to your company and your CSR strategy. In addition to these central government institutions, the local authorities, such as the Environmental Protection Bureaus and Departments of Corporate Social Responsibility in China.

For China is typical regional differentiation of introduction of CSR policy, its forms, scope and enforcement. It is clear that to CSR strategy is more used to companies from the developed parts of China (Beijing, Shanghai and the Pearl River Delta), than it can be observed in other regions [6].

In practice, CSR in China has always been the "ideological and political work" of the administrative departments. The Chinese government has frequently used awareness campaigns to promote corporate social responsibility, for example, by holding meetings and displaying slogans such as "serve the people" and "socialist spiritual civilization". 
Zhang D., Li B., Morse S. \& Kambhamptati U. stand out next periods of Chinese CSR evolution that are linked to economic reforms:

(1) The socialist planned-economy period (1950-1978) - that has typical features of socialist economy: state plays the main role in the all processes and CSR turns out in compliance with legislative, especially Labour Law.

(2) The transitional period (after 1978) when China launched its transformation from a socialist planned economy to a socialist market economy- private sector received its development and new CSR initiatives become possible in accordance with business strategy of company [3].

Now we will turn to "Harmonious Society". In 2005, Chinese president $\mathrm{Hu}$ Jintao introduced his vision of a "Harmonious Society" for China. This vision was followed, in 2006, by the "Building a Harmonious Society Policy" released by the Chinese Communist Party. Though the vision and the policy do not explicitly refer to CSR, it is admitted that CSR was soon, and is still, considered instrumental for achieving the socio-economic goals of this new policy. Indeed, the policy marked the start of a series of public CSR activities. New laws with respect to CSR have been passed, while a series of other CSR activities were undertaken by various governmental bodies and now trickle down at the local levels. The most significant law provision with respect to CSR is the 2005 amendment to the Company Law. The Company Law, which is the law detailing general operating framework for companies, refers to general principles of Social Responsibility for companies.

The "Harmonious Society" should be achieved thanks to the Scientific Development Concept, which is the current Chinese ideological guidance, and calls for sustainable development and social welfare" such as the gap between rural and urban development, unequal income distribution, insufficiency of household wealth, ecological degradation, and lack of efficient use of resources. CSR is also seen as an important component of companies' competitiveness, as put forward in the CSR Guidelines for StateOwned Enterprises. Interestingly, CSR is also considered as a driver for corporate innovation. This Harmonious Society Policy comes after more than two decades of economic reforms towards a "socialist market economy" and of opening to the world. These decades have allowed a sustained and amazing economic growth. The new policy aims at achieving social and environmental goals, in addition to economic goals. It is a significant shift.

First, the government believes that improving labor wages and conditions can contribute significantly to relieve social tensions and achieve the so-called Harmonious Society. It wants to move from a cheap-labor, export-oriented economy to an economy with a large and dynamic national market, relying on enhanced wages [4]. In this we see the similarities with the Ukrainian realities, where a large out flow of labor to other countries due to the low level of remuneration for our employee. Experience in solving this problem can be useful.

The main forms and steps for the development of CSR by Chinese companies are increasing the number of social reports and the development of charitable and volunteer activities. So, according to one study, 582 CSR reports of different forms were released by Chinese companies in 2009, about three-and-a-half times the number produced the year before. The Shanghai and Shenzhen stock exchanges have supported the burgeoning CSR movement by publishing papers about why CSR in general is important for listed companies.

"There is a strong movement by Chinese firms to im- plement CSR and integrate aspects of CSR into their own operations, such as making sure their supply chains are green," says Casey Wilson, who runs Wokai, an organization that helps micro-entrepreneurs in China start small businesses and lift themselves out of poverty.

Although embryonic, the notion of private philanthropy and volunteerism is slowly emerging as well. A rising number of private foundations have been established by wealthy Chinese. Observers say the Sichuan earthquake in 2008 marked a key change in Chinese CSR, generating an unprecedented number of donations and an outpouring of volunteerism.

Many companies in China find that employee volunteerism encourages a sense of camaraderie that provides huge benefits to the workplace. "A lot of international firms based in China support us because it's a way to boost employee morale," Wilson says.

Historically in China, Lyon notes, volunteerism was focused on people helping out their own family members. "Until recently, the state took care of everything, so public philanthropy and volunteerism are new concepts," he says. But he notes that movie star Jet Li has launched a foundation and brought a new focus - and a famous face to philanthropy and charitable giving in China (Corporate Social Responsibility Emerges in China).

The concept of corporate involvement in promoting greater social responsibility was officially put forward for the first time in the Decision on Building a Harmonious Society issued by the Central Party Committee in 2006. The concept of social responsibility has since been mentioned in top-level official documents and in speeches by senior government officials. At the Third Plenary Session of the 18th Central Party Committee on comprehensive reform in November 2013, social responsibility was announced as one of eight focus areas for further reform for Chinese SOEs. A number of Central Government ministries have also developed guidelines and policies to promote CSR in different sectors. For example, the Ministry of Commerce has issued official documents urging Chinese companies investing or operating overseas to implement CSR. A national CSR guideline for the electronics industry in China is expected to be issued by the Ministry of Industry and Information Technology within the next two years. Local governments in certain regions have also been actively driving the development of CSR in China. The results of the online survey reveal that local governments in the first-tier cities and Eastern and Southern China regions are viewed as being the most proactive in this regard. By the end of 2014, governments in at least eight provinces and 18 cities had published CSR-related guidelines or standards for local businesses [6].

At the same time, David De Cremer notes that adopting CSR as a company philosophy in China seems to be more challenging than could be expected. It is no secret that most businesses have adhered for a long time to Milton Friedman's wisdom that business should only care about making profits for their shareholders. Since the outbreak of the financial crisis at the end of 2007 - early 2008, this trusted wisdom, however, has been challenged by many in society.

Now we can observe the next situation: in developed countries CSR is a company strategy and sometimes even philosophy, at the same time in developing countries CSR now only begins to get its development and still remaining incomprehensible. Whereas the Chinese market is the biggest in the world, it faces some difficulties in the term of CSR implementation. Nowadays the concept of CSR is becoming famous and applicable in Chinese society that is connected with the fact of realizing main hazards of 
manufacturing direction of Chinese economy. Society more and more understand the real disadvantages of this situation and criticize businesses and manufacturers. As the result of this, companies that want to become leaders in Chinese market are to become more social oriented. And this seems to be one of the main incentives to develop CSR in China. Now CSR practices are not only ethical actions in the developed world anymore, it receives its shared business value, that has led to understanding that companies can receive also commercial success when they provide CSR practices. All of abovementioned has led the Chinese companies to develop CSR practices and initiatives. But, at the same time, there are only few examples when Chinese companies can combine their profitability, responsibility and sustainability. The increase of numbers of this persuasive examples can become a decent base for the further development of Chinese market and approve its leading world position in different ways [7].

The state actively promotes the development of CSR, adopting relevant laws or making changes to existing ones. Activities include most main initiatives at the national level - though some are not included. This document includes only some selected initiatives at the provincial and municipal levels, as their number makes it difficult to embrace them all [4].

Table 1. - Chinese CSR legislation*

\begin{tabular}{|c|c|c|}
\hline Law & $\begin{array}{l}\text { Year of } \\
\text { adopting }\end{array}$ & Main characteristic \\
\hline Company Law & $\begin{array}{l}\text { Amended } \\
2005\end{array}$ & $\begin{array}{l}\text { It explicitly includes CSR } \\
\text { Article 5: "A company must, when engaging in business activities, abide by the } \\
\text { laws and administrative regulations, observe social morals and commercial } \\
\text { ethics, act with integrity and good faith, accept supervision of the government } \\
\text { and the public, and undertake social liability." }\end{array}$ \\
\hline $\begin{array}{l}\text { Labor Law of the } \\
\text { People's Republic of } \\
\text { China }\end{array}$ & 1998 & $\begin{array}{l}\text { Article } 5 \text { The States hall take various measures to promote employment, develop } \\
\text { vocational education, lay down labor standards, regulate social incomes, perfect } \\
\text { social insurance system, coordinate labor relationship, and gradually raise the } \\
\text { living standard of laborers. }\end{array}$ \\
\hline Labor Contract Law & 2008 & $\begin{array}{l}\text { Includes } 98 \text { articles. Its provisions aim at increasing job security and regulating } \\
\text { temporary-jobs with more stringent conditions. It limits overtime, sets minimum } \\
\text { wages, and mandate companies to pay to laid-off employees one month salary } \\
\text { for each year worked. It establishes social security accounts for employees. } 14 \\
\text { reasons for dismissing an employee are established, thus regulating dismissals. }\end{array}$ \\
\hline $\begin{array}{l}\text { Law on the Protection } \\
\text { of Rights and Interests } \\
\text { of Women }\end{array}$ & 2002 & Chapter IV. Rights and Interests Relating to Work. \\
\hline Production Safety Law & 2002 & Chapter II. Guarantee of Safety by Production and Business Operation Entities. \\
\hline $\begin{array}{l}\text { Article } 26 \text { of the } \\
\text { Constitution }\end{array}$ & $\begin{array}{c}1982 \\
\text { amended } \\
1988,1993\end{array}$ & $\begin{array}{l}\text { Article } 26 \text { - "The state protects and improves the living environment and the } \\
\text { ecological environment, and prevents and controls pollution and other public } \\
\text { hazards. The state organizes and encourages a forestation and the protection of } \\
\text { forests." }\end{array}$ \\
\hline $\begin{array}{l}\text { Environmental } \\
\text { Protection Law }\end{array}$ & 1989 & $\begin{array}{l}\text { This Law is formulated for the purpose of protecting and improving people's } \\
\text { environment and the ecological environment, preventing and controlling pollution } \\
\text { and other public hazards, safeguarding human health and facilitating the } \\
\text { development of socialist modernization. } \\
\text { The plans for environmental protection formulated by the state must be } \\
\text { incorporated into the national economic and social development plans; the state } \\
\text { shall adopt economic and technological policies and measures favorable for } \\
\text { environmental protection so as to coordinate the work of environmental } \\
\text { protection with economic construction and social development. }\end{array}$ \\
\hline $\begin{array}{l}\text { Law on the } \\
\text { Environmental Impact } \\
\text { Assessment }\end{array}$ & 2003 & $\begin{array}{l}\text { This Law is formulated for the purpose of realizing sustainable development } \\
\text { strategy, preventing ad verse impacts on the environment from implementation } \\
\text { of plans and construction projects, and promoting coordinative development of } \\
\text { the economy, society and environment. }\end{array}$ \\
\hline $\begin{array}{l}\text { Law on the Promotion } \\
\text { of Clean Production }\end{array}$ & 2003 & $\begin{array}{l}\text { Article } 4 \text { The State encourages and promotes cleaner production. The State } \\
\text { Council and the local people's government sator above the county levels hall in } \\
\text { corporate cleaner production into their plans for national economic and social } \\
\text { development and plans for environment protection, recourses utilization, } \\
\text { industrial development, regional development, etc. }\end{array}$ \\
\hline $\begin{array}{l}\text { Law on Prevention and } \\
\text { Control of Water } \\
\text { Pollution }\end{array}$ & $\begin{array}{l}1984 \\
\text { Amended } \\
2008\end{array}$ & $\begin{array}{l}\text { Amendment includes: "Enterprise held directly responsible for causing severe } \\
\text { water pollution incidents and others with direct responsibility will be fined up to } \\
\text { half of their income in the previous year." }\end{array}$ \\
\hline
\end{tabular}

${ }^{*}$ Build on the base of [4]

CSR activities in China involve greater government involvement than similar initiatives in western countries, where CSR strategies are driven mostly by private sector or non-government organizations. In China, state-owned corporations usually have the more comprehensive CSR programs. Chinese CSRinitiatives include laws and regulations, governmental instructions and guidelines, nongovernmental standards and organizations [8].
The new format of CSR, promulgated by the government, has been viewed as a marketing tool that is essential for companies' success in today's business environment in China. Despite this common perception, we found differences between companies operating at the national level and those operating globally.

Traditionally companies at the national levels was accustomed to the implicit form of CSR, that was built in 
existing corporate infrastructure. But nowadays Chinese companies are tend to adopt the explicit form of CSR as a tool to show their aim to act in accordance with values and standards of national business environment.

The main norms and values of CSR were established by the state on the national level and detailed on regional levels by regional governments. All this lead to the possibility to cover all local needs and decent usage of own resources, and as the result to economic development and success of the whole country. In the circumstances of institutionalized decentralization, companies received the possibility to show by CSR reporting or working in connection with the authorities their complianceto the norms and values that are stated on this local level.

To the contrast, companies that operate on the international level is under the pressure not only of Chinese government but also global leaders, that established norms and values of CSR policy. The Chinese companies that act on the global market are tend to raise the level oh national CSR strategy and CSR reports. In this case they increase their CSR standards with the support of regional governments and can compete with the global norms and values.

It is under the central government's strategy to support Chinese entrepreneurships to occupy the share on global market and compete with the leaders in international business society [10].

Taking into account the fact that leading positions on Chinese market are occupied by state-owned companies and in accordance with this they are influenced by the state, and as the result they connect with the government to achieve their own political goals. This describes the existing problem in China of a considerable gap between companies that operate on international level and have their own share on the global market and companies that do business on domestic level [9].

The study that took place in 2014 showed: According to the results of the online survey, "compliance with Central Government policy, legislation and regulations", "reputation enhancement" and "requirements of international clients" are perceived as the top three incentives for companies to implement CSR in China.

Respondents pointed out as key incentives for Chinese CSR development the main three drivers, and namely "government /regulators", "international buyers with CSR requirements" and "media".

According with online survey was mentioned three main obstacles for providing CSR initiatives by Chinese companies, and namely: "insufficient monitoring of compliance", "lack of long-term CSR strategy/policy" and "lack of knowledge and CSR professionals". As well as the absence of a long-term CSR strategy or policy and lack of decent knowledge about CSR also can interfere to effective implementation of CSR strategy in nowadays Chinese business.

From this survey we also knew that entrepreneurs still consider CSR as a thing that cuts profit of their company. Respondents noted the "cost saving" as the least incentive for CSR development at the Chinese entrepreneurships. Since the understanding of importance of CSR implementation in Chinese companies is still quite low, the question of main incentives of CSR providing arises. According to abovementioned survey the main incentive for implementation of CSR and its development in Chinese society is governmental policy in this sphere. Companies are tend to be complained with legislative requirements.

As this survey respondents' mentioned: the government is the key driver of CSR development in China. Nowadays legislative base has already covered all main topics and issues of CSR's appliance: labor conditions, environmental protection, consumer rights and anti-corruption. It is also pointed out that some of this issues (labor condition, environmental protection and some others) in China are even outclassed international standards. At the same time, there are some obstacles that can decrease the development of CSR: insufficient enforcement and the relatively low business cost for violating such regulations. That can considerably slow down implementation of CSR in Chinese companies' agenda [6].

Thus, we see that respondents see the Government as the main subject of CSR development. The state actually introduces certain measures, accepts new ones or changes existing legal acts for the development of CSR initiatives by business entities. At the same time, however, respondents indicate that entrepreneurs themselves still consider CSR a means of reducing their profits. Actually, this does not correspond to reality, since CSR, by contrast, is a means of improving the image of the enterprise, and hence attracting new customers.

For Ukraine the experience of compulsory social reporting for state-owned enterprises is useful. And, as it was presented, state-owned enterprises are considered to be more socially responsible in China, while in our country it is the opposite. The development of this sphere is important for the Ukrainian SERE, as social reporting is one of its instruments.

\section{Conclusions}

The conclusion can be as follows: the experience of state regulation in the sphere of social responsibility of business is very useful for Ukrainian enterprises. First, China is a country that is actively pursuing reforms and is actively developing in the global economy, occupying its leading position. It is believed that the very responsibility of business is the basis of entrepreneurship in this country, but this is not entirely true. Since the early 20 th century, the government has been actively focusing on CSR issues, improving legislation or adopting new laws that have an impact on this area. Secondly, in China state-owned enterprises are considered to be more socially responsible than private ones, which is related to compulsory social reporting by state-owned enterprises, which is enshrined in law. In addition, the state is now paying much attention to the environmental component of CSR, due to the high level of environmental pollution and industrial orientation of the country. The solution of these problems also becomes an opportunity for the Ukrainian present due to the industrial character of the Ukrainian economy.

Hence, the main directions that can be used to develop our SERE are legislative introduction of compulsory social reporting for entrepreneurs, as well as improvement of the legislative framework in the field of environment, by increasing the standards of production and, consequently, improving the quality of life of the population.

\section{REFERENCES}

1. Commissioned by the ministry of Foreign Affairs [Netherlands] (2016),Corporate Social Responsibility in China. Available at: https://english.rvo.nl/sites/default/files/2017/03/ Factsheet\%20CSR\%20China.pdf.

2. Buhmann, K. (2005). Corporate Social Responsibility in China: Current Issues and Their Relevance for Implementation of Law. The Copenhagen Journal of Asian Studies, 22, pp. 62-91, available at: http://ej.lib. cbs.dk/index.php/cjas/article/view/521/551.

3. Zhang, D. and Morse, S. and Kambhamptati, U., \& Li, B. (2014). Evolving corporate social responsibility in China. Sustainability, 6, 7646-7665. DOI: 10.3390/su6117646. 
4. CSR Frame works in China and the European Union Insights for CSR Workshops, CHINA-EUROPA FORUM'S (June 2010), available at: http://www.chinaeuropa-forum.net/bdfdoc1704_en.html.

5. Mullich, Joe (2009), Corporate Social Responsibility Emerges in China. The Wall Street Journal. Available at: http:// online.wsj.com/ad/article/chinaenergy-responsibility.

6. CSR Asia (2016). A study on corporate social responsibility development and trends in China. Embassy of Sweden, Beijing Available at: http://www.csr-asia.com/report/CSR-developmentand-trends-in-China-FINAL-hires.pdf.

7. Huawei as a Case Study (2016). Corporate Social Responsibility in China. The European business review, available at: http://www.europeanbusinessreview.com/corporate-socialresponsibility-csr-in-china-huawei-as-a-case-study/.
8. Tang, B. (2012). Contemporary corporate social responsibility (CSR) in China: A case study of a Chinese compliant. Seven Pillars Institute Moral Cents, 1(2), 13-22

9. Parsa, S. \&Tang, G., \& Dia, N. (2016). How do Chinese businesses view corporate social responsibility? Institutional Institute for Sustainable Development Charitable Trusts (Academic), available at: https://www.icaew.com/-/media/corporate/ files/technical/research-and-academics/tecpln14774charitieschinese-web.ashx.

10. Shambaugh, David (2014). China at the Crossroads: Ten Major Reform Challenges. Center for East Asian Policy Studies. John L. Thornton China Center. The Brookings Institution, Washington D.C., USA. Available at: https://www.brookings.edu/ wp-content/uploads/2016/06/01-china-crossroads-reformchallenges-shambaugh-b.pdf.

Делини Марина,

кандидат экономических наук, дочент,

Национальный педагогический университет им. М. П. Драгоманова

\section{РАЗВИТИЕ КОРПОРАТИВНОЙ СОЦИАЛЬНОЙ ОТВЕТСТВЕННОСТИ В КНР: ОПЫТ ДЛЯ УКРАИНЫ}

В статье представлен теоретический обзор государственного регулирования социальной ответственности бизнеса в Китае. Выбор страны для исследования обоснован успешностью проводимых в ней экономических реформ, актуальностью инструмента корпоративной социальной ответственности для улучшения экологической обстановки в стране, а также для дополнительного контроля негосударственного сектора экономики.

Определены основные законодательные акты, регулирующие эту сферу. Указана обязательность социальной отчетности для государственных предприятий. Отмечено, что важной сферой регулирования социальной ответственности бизнеса со стороны государства является охрана окружающей среды из-за большого уровня загрязнения и промышленного характера экономики страны. Определены направления для развития украинской социально-экономической ответственности предпринимательства, основанные на опыте Китая. В частности, это законодательное внедрение обязательной социальной отчетности для предпринимателей, а также совершенствование законодательной базы в области охраны окружающей среды путем повышения стандартов производства.

Ключевые слова: социально-экономическая ответственность бизнеса; корпоративная социальная ответственность; социальная отчетность; благотворительность; государственные предприятия.

Деліні Марина,

кандидат економічних наук, дочент,

Наиіональний педагогічний університет ім. М. П. Драгоманова

\section{РОЗВИТОК КОРПОРАТИВНОї СОЦІАЛЬНОї ВІДПОВІДАЛЬНОСТІ В КНР: ДОСВІД ДЛЯ УКРАї̈И}

У статті представлено теоретичний огляд державного регулювання соціальної відповідальності бізнесу в Китаї. Вибір країни для дослідження обґрунтовано успішністю проваджуваних у ній економічних реформ, актуальністю інструменту корпоративної соціальної відповідальності для поліпшення екологічного становища в країні, а також для додаткового контролю недержавного сектора економіки.

Визначено основні законодавчі акти, які регулюють цю сферу. Зазначено обов'язковість соціальної звітності для державних підприємств. Зауважено, що важливою сферою регулювання соціальної відповідальності бізнесу з боку держави є охорона навколишнього середовища через великий рівень забруднення та промисловий характер економіки країни. Визначено напрями для розвитку української соціально-економічної відповідальності підприємництва, основані на досвіді Китаю. Зокрема, це законодавче впровадження обов'язкової соціальної звітності для підприємців, а також вдосконалення законодавчої бази в галузі охорони навколишнього середовища шляхом підвищення стандартів виробництва.

Ключові слова: соціально-економічна відповідальність бізнесу; корпоративна соціальна відповідальність; соціальна звітність; благодійність; державні підприємства.

() Деліні Марина

Надійшла до редакції 29.11.2017 